\title{
CORROSION INHIBITION OF 1,4-DIMETHYL PHENYL-N,N-DIMETHYLANILINIUM DIBROMIDE SALT ON MILD STEEL IN HCI SOLUTION
}

\section{AYSSAR NAHLÉ, NADA ABDEL-SAMAD ALHAMMADI, IDEISAN IBRAHIM ABU-ABDOUN and IBRAHIM ABDEL-RAHMAN}

Department of Chemistry

College of Sciences

University of Sharjah

Sharjah, P. O. Box 27272

United Arab Emirates

e-mail: anahle@sharjah.ac.ae

\begin{abstract}
Electrochemically and weight loss measurements were carried out to study the effect of laboratory synthesized 1,4-dimethyl phenyl-N,N-dimethylanilinium dibromide salt (DMPMA) on the corrosion inhibition of mild steel in $1.0 \mathrm{M} \mathrm{HCl}$ solution containing various concentrations $\left(1.0 \times 10^{-3} \mathrm{M}\right.$ to $\left.1.0 \times 10^{-7} \mathrm{M}\right)$ at temperatures ranging from $303 \mathrm{~K}$ to $343 \mathrm{~K}$.

1,4-dimethyl phenyl-N,N-dimethylanilinium dibromide salt was found to be very efficient inhibitor for mild steel in $1.0 \mathrm{M} \mathrm{HCl}$ solution, reaching about $93 \%$ at the concentration of $1.0 \times 10^{-3} \mathrm{M}$ at $303 \mathrm{~K}$. The percentage of inhibition in the presence of this inhibitor decreased with temperature which indicating a physical adsorption was the predominant inhibition mechanism. This inhibitor will have application in industries, where hydrochloric acid solutions at elevated temperatures are used to remove scale and salts from steel surfaces, such as acid cleaning of tankage and pipeline, and may render dismantling unnecessary.
\end{abstract}

Keywords and phrases: corrosion, inhibitor, 1,4-dimethyl phenyl-N,N-dimethylanilinium dibromide, Temkin adsorption isotherm.

Received November 15, 2018

(C) 2019 Scientific Advances Publishers 


\section{Introduction}

The use of inhibitors to minimize the corrosion of metals is an important subject in industry and research. Corrosion increases the running costs and reduces plant efficiency, availability, and product quality.

Organic compounds containing aromatic rings, polar groups, and/or $\mathrm{N}, \mathrm{P}, \mathrm{O}, \mathrm{S}$ elements are found to be the most efficient inhibitors. The inhibition occurs via adsorption of the inhibitor at the metal/solution interface. This inhibition reduces the corrosion current produced from the adsorption process.

The study of corrosion inhibition of mild steel in aggressive acidic media was widely investigated and became an important industrial topic for research. Acidic $\mathrm{HCl}$ solutions are usually used in industry to remove scale and salts from steel surfaces, cleaning tanks and pipelines. This treatment may be prerequisite for coating by electroplating, galvanizing or painting techniques. An inhibitor must be added to the acidic media in order to prevent or minimize the dissolution of the underlying metal. This inhibitor displaces water molecules at the metal surface and adsorbs at the metal/solution interface, so that the metal surface will be protected from corrosion by forming a barrier film on metal surface.

Extensive literatures exist on corrosion inhibition in acidic media; however detailed knowledge of the mode of action and the mechanism of inhibition still needs more investigation.

Organic nitrogen-containing compounds as corrosion inhibitors for different metals were studied widely by many authors [1-18]. Sulphurcontaining inhibitors [19-26] and phosphorus organic inhibitors were investigated by other authors [27-30]. The effect of structure on the inhibition of some organic compounds was also studied [30, 31]. 
The aim of this work was to study the corrosion inhibition efficiency of the synthesized compound 1,4-dimethyl phenyl-N,N-dimethylanilinium dibromide (DMPMA) on mild steel in $1.0 \mathrm{M} \mathrm{HCl}$ solution (Scheme 1) using electrochemical, and weight loss measurements.

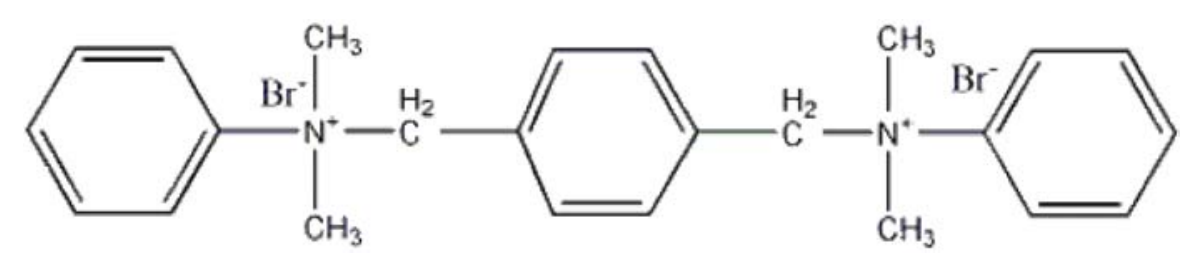

Scheme 1. 1,4-dimethyl phenyl-N,N-dimethylanilinium dibromide.

\section{Experimental Details}

\section{Synthesis of 1,4-dimethyl phenyl-N,N-dimethylanilinium dibromide}

The 1,4-dimethyl phenyl-N,N-dimethylanilinium dibromide salt (3) was prepared by refluxing two molar equivalent from $\mathrm{N}, \mathrm{N}$-dimethylaniline (1) with one molar equivalent from 1,4-dibromethylbenzene (2) in acetone as shown in the procedure below (Scheme 2):

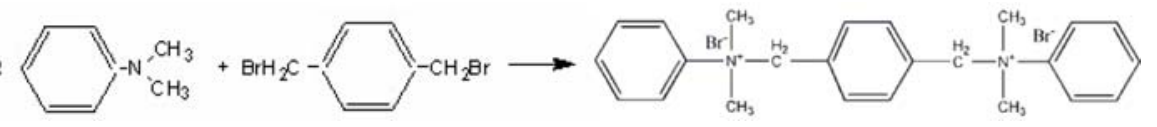

(1)

(2)

(3)

Scheme 2. Synthesis of 1,4-dimethyl phenyl-N,N-dimethylanilinium dibromide.

A mixture of 8.00 grams $(0.066 \mathrm{~mol})$ of $\mathrm{N}, \mathrm{N}$-dimethylaniline (1), and 8.72 grams of 1,4 -dibromethylbenzene $(0.033 \mathrm{~mol})(2)$, in $500 \mathrm{~mL}$ carbon tetrachloride $\left(\mathrm{CCl}_{4}\right)$ was refluxed for 6 hours. After cooling to room temperature, a crystalline off-white precipitate (3) was collected by filtration, then washed with excess diethyl ether and dried. Dissolution in small amount of chloroform and addition of excess diethyl ether gave the pure salt (3) in 80 percent yield with a melting point between $133^{\circ} \mathrm{C}$ and $136^{\circ} \mathrm{C}$. 


\section{Electrochemistry}

\subsection{Electrode preparation}

A $5 \mathrm{~mm}$ diameter piece cut from a mild steel rod (IS 226 containing $0.18 \% \mathrm{C}, 0.6 \% \mathrm{Mn}$, and $0.35 \% \mathrm{Si}$ ) supplied by "Reliable Steel Traders", Sharjah, UAE, formed the working electrode; and was mounted, using Araldite epoxy resin, in a glass tube that fits in the electrochemical cell (Figure 1). Prior to each experiment, the working mild steel electrode was abraded using a series of carborundum papers starting with 600 grades and ending with 1200 grades. The electrode surface was then polished with $0.3 \mu \mathrm{m}$ alumina on cloth, washed with deionized distilled water, and rinsed with pure ethanol before being transferred to the electrochemical cell that contained deaerated fresh electrolyte. 


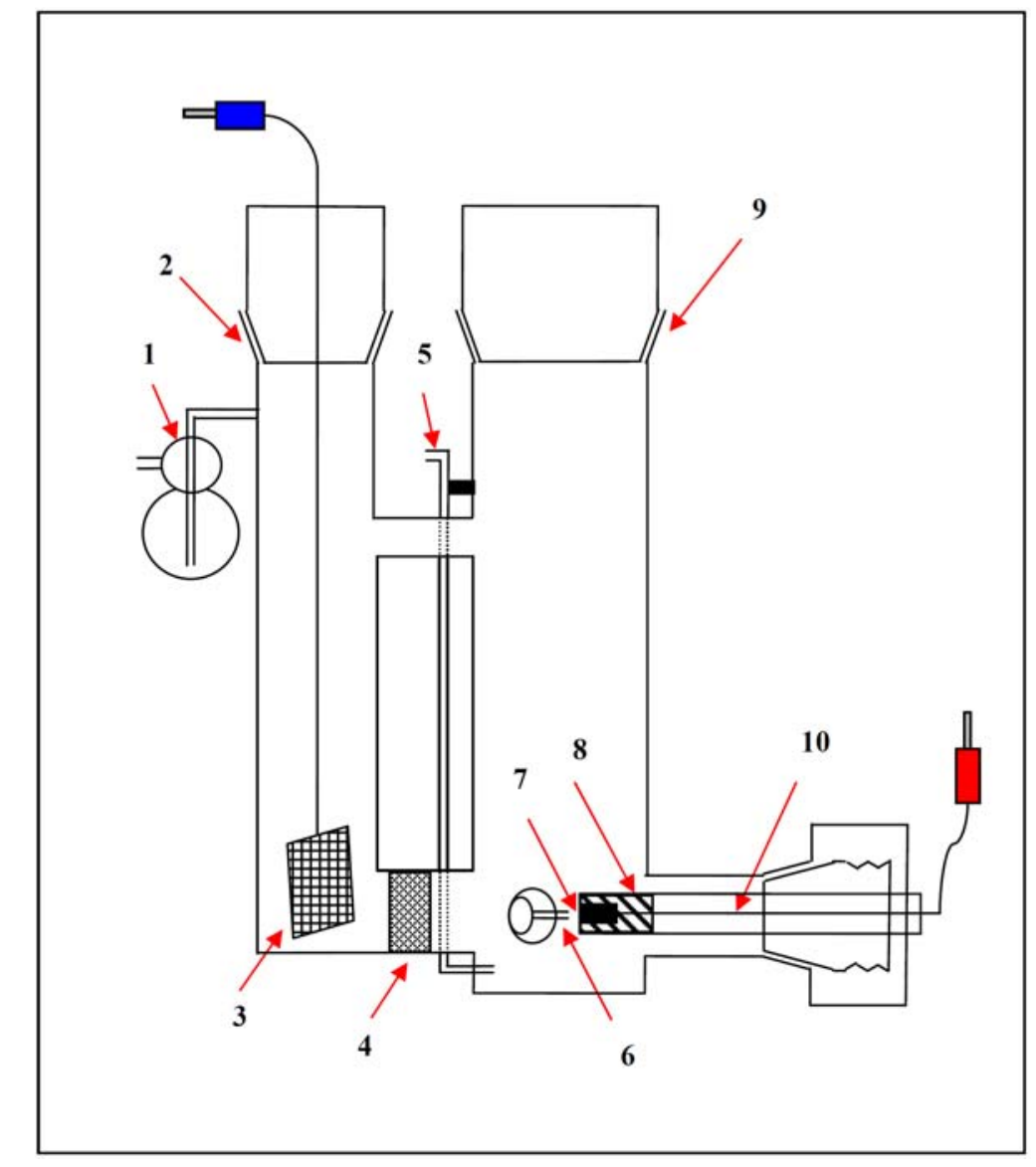

Figure 1. Electrochemical cell. (1) gas bubbler, (2) B 12 glass socket, (3) platinum gauze (counter electrode), (4) glass frit, (5) inlet for nitrogen gas, (6) luggin capillary (reference electrode), (7) iron rod (working electrode), (8) epoxy resin, (9) B 24 glass socket, and (10) copper wire.

\subsection{Instrumentation}

The electrochemical cell (Figure 1) consisted of a mild steel working electrode (WE), a saturated calomel electrode (SCE) as a reference electrode (RE), and platinum gauze counter electrode (CE). Prior to each experiment, the electrolyte was deaerated by nitrogen bubbling. The cell was designed in a way that the nitrogen was allowed to escape into the solution, precluding its collection at the electrode surface. 
In order to protect the working electrode from any substance that may be produced at the counter electrode during the electrochemical reactions, the counter-electrode compartment was separated from the working-electrode compartment with a glass frit.

A PC controlled AUTOLAB PGSTAT128N Modular Potentiostat (electrochemical workstation) (supplied from Metrohm) capable of driving currents up to $\pm 800 \mathrm{~mA}$ with an output potential across the cell of up to $\pm 10 \mathrm{~V}$ was used for the measurements.

\subsection{Measuring procedure}

Electrochemical corrosion measurements (Tafel plots) were carried out on the mild steel electrode, prepared as described before, in $1.0 \mathrm{M}$ $\mathrm{HCl}$ and in $1.0 \mathrm{M} \mathrm{HCl}$ containing various concentrations of the prepared DMPMA inhibitor. The concentration of the inhibitor ranged from $1.0 \times 10^{-7} \mathrm{M}$ to $1.0 \times 10^{-3} \mathrm{M}$. Owing to the restricted solubility of DMPMA inhibitor in $1.0 \mathrm{M} \mathrm{HCl}$, higher concentrations could not be prepared.

The electrochemical cell was filled with $60 \mathrm{~mL}$ of the electrolyte. The solution was deaerated with nitrogen gas and the WE equilibrium potential was monitored and recorded vs. SCE until it reached a steady state. The electrode potential was scanned between overpotentials of $-100 \mathrm{mV}$ to $+100 \mathrm{mV}$ vs. SCE at a sweep rate of $1 \mathrm{mV} \cdot \mathrm{s}^{-1}$.

Replicate measurements were carried out in order to ensure reproducibility of the results.

\subsection{Results and discussions}

Figure 2 shows the anodic and cathodic polarization curves (Tafel plot) of the mild steel electrode in deaerated 1. $0 \mathrm{M} \mathrm{HCl}$ solution with and without the addition of various concentrations of 1,4-dimethyl phenylN,N-dimethylanilinium dibromide (DMPMA). The presence of the inhibitor affected both the anodic and cathodic branches of the curve as it can be clearly seen in Figure 2. It is clearly noticed that the corrosion 
current decreased with the increase of the concentration of DMPMA inhibitor (Table 1). In the absence of inhibitor (in $1.0 \mathrm{M} \mathrm{HCl}$ ), the corrosion current was found to be $0.80606 \mathrm{~mA}$, and reached $0.10949 \mathrm{~mA}$ at $1.0 \times 10^{-3} \mathrm{M}$ of DMPMA inhibitor in $1.0 \mathrm{M} \mathrm{HCl}$ (Table 1 ).

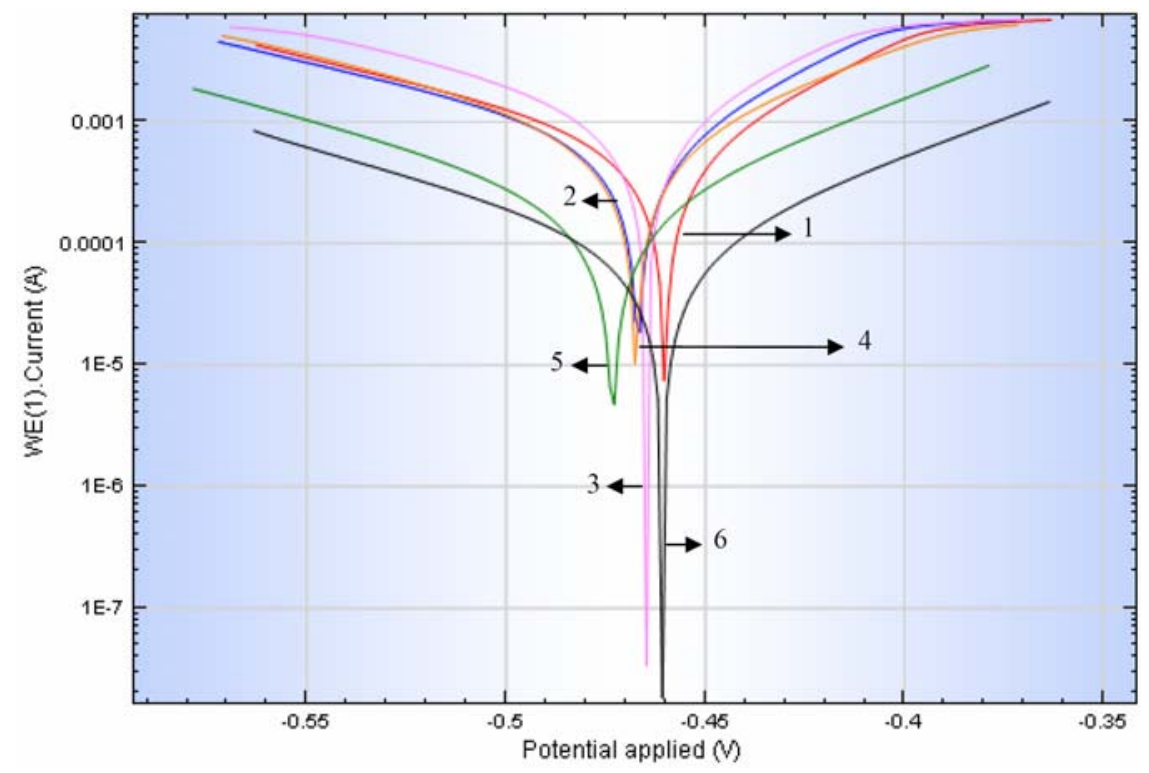

Figure 2. Anodic and cathodic polarization curves of mild steel in an uninhibited $1.0 \mathrm{M} \mathrm{HCl}$ solution and in $1.0 \mathrm{M} \mathrm{HCl}$ containing various concentrations of 1,4-dimethyl phenyl-N,N-dimethylanilinium dibromide salt.

(1) $\quad 1.0 \mathrm{M} \mathrm{HCl} ; \quad$ (2) $1.0 \mathrm{M} \mathrm{HCl}+1.0 \times 10^{-7} \mathrm{M} \quad$ inhibitor; $1.0 \mathrm{M} \mathrm{HCl}+1.0 \times 10^{-6} \mathrm{M}$ inhibitor; (4) $1.0 \mathrm{M} \mathrm{HCl}+1.0 \times 10^{-5} \mathrm{M}$ inhibitor; (5) $1.0 \mathrm{M} \mathrm{HCl}+1.0 \times 10^{-4} \mathrm{M}$ inhibitor; and (6) $1.0 \mathrm{M} \mathrm{HCl}+1.0 \times 10^{-3} \mathrm{M}$ inhibitor. 
Table 1. Tafel corrosion currents and percent inhibitions of 1,4-dimethyl phenyl-N,Ndimethylanilinium dibromide various concentrations in $1.0 \mathrm{M} \mathrm{HCl}$ at room temperature

\begin{tabular}{|c|c|c|c|c|c|c|}
\hline & $1.0 \mathrm{M} \mathrm{HCl}$ & $\begin{array}{c}1.0 \mathrm{M} \mathrm{HCl} \\
+1.0 \times 10^{-7} \mathrm{M}\end{array}$ & $\begin{array}{c}1.0 \mathrm{M} \mathrm{HCl} \\
+1.0 \times 10^{-6} \mathrm{M}\end{array}$ & $\begin{array}{c}1.0 \mathrm{M} \mathrm{HCl} \\
+1.0 \times 10^{-5} \mathrm{M}\end{array}$ & $\begin{array}{c}1.0 \mathrm{M} \mathrm{HCl} \\
+1.0 \times 10^{-4} \mathrm{M}\end{array}$ & $\begin{array}{r}1.0 \mathrm{M} \mathrm{HCl} \\
+1.0 \times 10^{-3} \mathrm{M}\end{array}$ \\
\hline $\begin{array}{l}\text { OCP/V vs. } \\
\text { SCE }\end{array}$ & -0.463 & -0.472 & -0.469 & -0.471 & -0.479 & -0.463 \\
\hline $\mathbf{b}_{\mathbf{a}} /(\mathbf{m V} / \mathbf{d e c})$ & 0.035564 & 0.054028 & 0.056219 & 0.065312 & 0.060943 & 0.059797 \\
\hline $\mathbf{b}_{\mathbf{c}} /(\mathbf{m V} / \mathbf{d e c})$ & 0.069716 & 0.10021 & 0.087065 & 0.079336 & 0.85116 & 0.074415 \\
\hline $\mathrm{E}_{\text {corr. }} / \mathrm{V}$ & -0.46016 & -0.46693 & -0.46478 & -0.4674 & -0.47332 & -0.46082 \\
\hline $\mathrm{I}_{\text {corr. }} / \mathrm{mA}$ & 0.80606 & 0.72840 & 0.55179 & 0.35070 & 0.22850 & 0.10949 \\
\hline $\begin{array}{c}\text { Polarity } \\
\text { Resistance } \Omega\end{array}$ & 27.581 & 25.695 & 16.384 & 27.545 & 94.633 & 201.46 \\
\hline $\begin{array}{c}\text { \% Inhibition } \\
\text { at } 25^{\circ} \mathrm{C}\end{array}$ & 0.000 & 9.63 & 31.54 & 56.49 & 71.65 & 86.42 \\
\hline
\end{tabular}


The percentage inhibition values of DMPMA at various concentrations in $1.0 \mathrm{M} \mathrm{HCl}$ were calculated according to the following equation and the results are shown in Table 1:

$$
\text { Percentage Inhibition }=\frac{\left(I_{\text {Corr. }}\right)_{\text {Uninh. }}-\left(I_{\text {Corr. }}\right)_{\text {Inh. }}}{\left(I_{\text {Corr. }}\right)_{\text {Uninh. }}} \times 100,
$$

where:

$$
\left(I_{\text {Corr. }}\right)_{\text {Uninh. }}=\text { Corrosion current in the uninhibited solution, }
$$

and

$$
\left(I_{\text {Corr. }}\right)_{\text {Inh. }}=\text { Corrosion current in inhibited solution. }
$$

Figure 3 shows the plot of the percentage inhibition versus the concentration of DMPMA. In this figure, the percentage inhibition increase gradually from about $10 \%$ with a concentration of $1.0 \times 10^{-7} \mathrm{M}$ inhibitor and reached a maximum value of about $86 \%$ with $1.0 \times 10^{-3} \mathrm{M}$. 


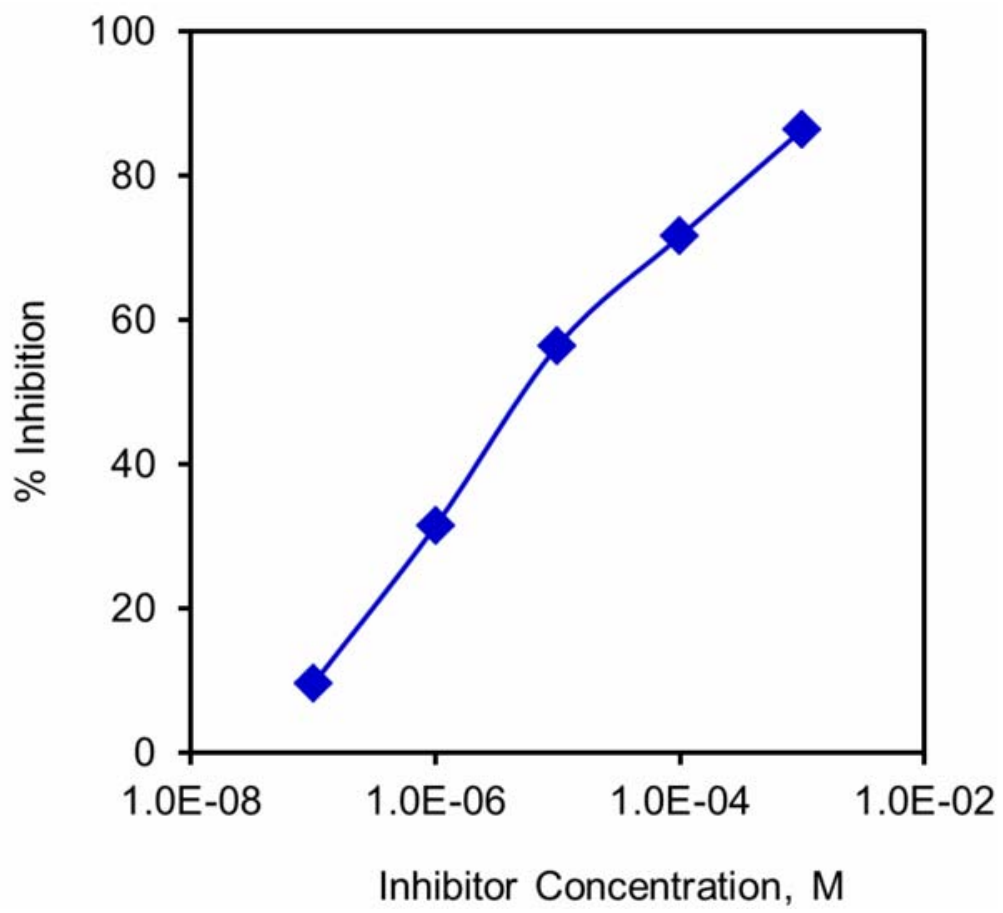

Figure 3. Percentage inhibition of different concentrations of 1,4dimethyl phenyl-N,N-dimethylanilinium dibromide on mild steel surface in $1.0 \mathrm{M} \mathrm{HCl}$ solution obtained from anodic and cathodic polarization curves.

\section{Effect of Temperature}

\subsection{Specimen preparation}

Rectangular specimens $(1.0 \mathrm{~cm} \times 2.3 \mathrm{~cm} \times 0.3 \mathrm{~cm})$ cut from large sheet of $3.0 \mathrm{~mm}$ thick mild steel (IS 226 containing $0.18 \% \mathrm{C}, 0.6 \% \mathrm{Mn}$, and $0.35 \% \mathrm{Si}$ ) supplied by "Reliable Steel Traders", Sharjah, UAE; were used for weight loss measurements. A $2 \mathrm{~mm}$ diameter hole was drilled close to the upper edge of the specimen and served to be hooked with a glass rod for immersion purposes. Prior to each experiment, the specimens were polished with 600 grade emery paper, rinsed with distilled water, degreased with acetone, dried, and finally weighed precisely on an accurate analytical balance. 


\subsection{Instrumentation}

For the weight-loss measurements, a $250 \mathrm{~mL}$ round bottom flask fitted with a reflux condenser and long glass rod which served to hook and immerse the specimen and in turn immersed in a thermally controlled water bath was used.

\subsection{Measuring procedure}

The flask was filled with $100 \mathrm{~mL}$ of $1.0 \mathrm{M} \mathrm{HCl}$ solution with and without (DMPMA) of various concentrations, then placed in water bath held at the desired temperature. The mild steel samples were immersed in the solution, and left there for exactly six hours, after that the samples were removed, rinsed with distilled deionized water, degreased with acetone, dried, and finally weighed precisely using an accurate analytical balance. This procedure was repeated with all samples with various concentrations of inhibitor $\left(1.0 \times 10^{-7} \mathrm{M}-1.0 \times 10^{-3} \mathrm{M}\right)$ and at various temperatures (303 K-343 K).

Three replicate measurements were carried out in order to ensure reproducibility of the results and the average values were reported.

\subsection{Results and discussions}

Weight loss measurements were carried out on the mild steel in $1.0 \mathrm{M}$ $\mathrm{HCl}$ in the absence and presence of (DMPMA) over a period of 6 hours. Table 2 represents the corrosion rates $\left[\mathrm{mg} . \mathrm{cm}^{-2} \cdot \mathrm{h}^{-1}\right]$, and the percentage efficiencies [\%] for the studied inhibitor with different concentrations $\left(1.0 \times 10^{-7} \mathrm{M}-1.0 \times 10^{-3} \mathrm{M}\right)$ at $303 \mathrm{~K}, 313 \mathrm{~K}, 323 \mathrm{~K}$, $333 \mathrm{~K}$, and $343 \mathrm{~K}$, respectively. The percentage efficiency was calculated according to the following equation:

$$
\% \text { Inhibition }=\frac{W_{\text {Uninh. }}-W_{\text {Inh. }}}{W_{\text {Uninh. }}} \times 100
$$

where: $\quad W_{\text {Uninh. }}=$ corrosion rate without inhibitor; and

$$
W_{\text {Inh. }}=\text { Corrosion rate with inhibitor. }
$$


Table 2. Effect of concentration of 1,4-dimethyl phenyl-N,N-dimethylanilinium dibromide on the corrosion rate $\left(\mathrm{mg} . \mathrm{cm}^{-2} \cdot \mathrm{h}^{-1}\right)$ and percentage efficiency of mild steel in $1.0 \mathrm{M} \mathrm{HCl}$ at various temperatures

\begin{tabular}{|c|c|c|c|c|c|c|c|c|c|c|}
\hline \multirow[b]{3}{*}{$\begin{array}{c}\text { Concentration } \\
\text { of inhibitor }\end{array}$} & \multicolumn{10}{|c|}{ Temperature / K } \\
\hline & \multicolumn{2}{|c|}{303} & \multicolumn{2}{|c|}{313} & \multicolumn{2}{|c|}{323} & \multicolumn{2}{|c|}{333} & \multicolumn{2}{|c|}{343} \\
\hline & $\begin{array}{l}\text { Corr. } \\
\text { Rate }\end{array}$ & $\begin{array}{c}\% \\
\text { Efficiency }\end{array}$ & $\begin{array}{l}\text { Corr. } \\
\text { Rate }\end{array}$ & $\begin{array}{c}\% \\
\text { Efficiency }\end{array}$ & $\begin{array}{l}\text { Corr. } \\
\text { Rate }\end{array}$ & $\begin{array}{c}\% \\
\text { Efficiency }\end{array}$ & $\begin{array}{l}\text { Corr. } \\
\text { Rate }\end{array}$ & $\begin{array}{c}\% \\
\text { Efficiency }\end{array}$ & $\begin{array}{l}\text { Corr. } \\
\text { Rate }\end{array}$ & $\begin{array}{c}\% \\
\text { Efficiency }\end{array}$ \\
\hline $1.0 \mathrm{M} \mathrm{HCl}$ & 0.446 & - & 0.910 & - & 2.244 & - & 4.812 & - & 9.537 & - \\
\hline $\begin{array}{c}1.0 \mathrm{M} \mathrm{HCl} \\
+1.0 \times 10^{-7} \mathrm{M}\end{array}$ & 0.349 & 21.87 & 0.825 & 9.39 & 2.044 & 8.90 & 4.535 & 5.78 & 9.278 & 2.72 \\
\hline $\begin{array}{c}1.0 \mathrm{M} \mathrm{HCl} \\
+1.0 \times 10^{-6} \mathrm{M}\end{array}$ & 0.260 & 41.30 & 0.605 & 33.54 & 1.681 & 25.08 & 4.084 & 15.14 & 8.229 & 13.71 \\
\hline $\begin{array}{c}1.0 \mathrm{M} \mathrm{HCl} \\
+1.0 \times 10^{-5} \mathrm{M}\end{array}$ & 0.075 & 83.18 & 0.183 & 79.94 & 0.585 & 73.95 & 2.226 & 53.75 & 5.689 & 40.35 \\
\hline $\begin{array}{c}1.0 \mathrm{M} \mathrm{HCl} \\
+1.0 \times 10^{-4} \mathrm{M}\end{array}$ & 0.028 & 93.70 & 0.070 & 92.31 & 0.196 & 91.25 & 0.548 & 88.62 & 2.138 & 77.58 \\
\hline $\begin{array}{c}1.0 \mathrm{M} \mathrm{HCl} \\
+1.0 \times 10^{-3} \mathrm{M}\end{array}$ & 0.010 & 97.80 & 0.030 & 96.70 & 0.085 & 96.23 & 0.213 & 95.58 & 0.505 & 94.70 \\
\hline
\end{tabular}


Figures 4 and 5 show the plots of the corrosion rate of mild steel with and without the inhibitor (DMPMA) versus the concentration of inhibitor at $303 \mathrm{~K}, 313 \mathrm{~K}, 323 \mathrm{~K}, 333 \mathrm{~K}$, and $343 \mathrm{~K}$. At $303 \mathrm{~K}$ (Figure 4), the corrosion rate dropped from $0.446 \mathrm{mg} . \mathrm{cm}^{-2} \cdot \mathrm{h}^{-1}(1.0 \mathrm{M} \mathrm{HCl}$ without inhibitor) to $0.349 \mathrm{mg} . \mathrm{cm}^{-2} \cdot \mathrm{h}^{-1}$ with $1.0 \times 10^{-7} \mathrm{M}$ of (DMPMA) inhibitor. Then the corrosion rate decreased slightly to reach $0.260 \mathrm{mg} . \mathrm{cm}^{-2} \cdot \mathrm{h}^{-1} \quad(41.30 \%$ inhibition) with $1.0 \times 10^{-6} \mathrm{M}$, followed by a steep decrease to reach $0.075 \mathrm{mg} . \mathrm{cm}^{-2} \cdot \mathrm{h}^{-1}$ with $1.0 \times 10^{-5} \mathrm{M} ;$ and finally, at higher concentrations $\left(1.0 \times 10^{-4} \mathrm{M}\right.$ and $\left.1.0 \times 10^{-3} \mathrm{M}\right)$ the decrease in the corrosion rate was slight and reached $0.028 \mathrm{mg} \cdot \mathrm{cm}^{-2} \cdot \mathrm{h}^{-1}$ and $0.010 \mathrm{mg} . \mathrm{cm}^{-2} \cdot \mathrm{h}^{-1}$ (93.7\% and 97.8\% inhibition), respectively (Table 2).

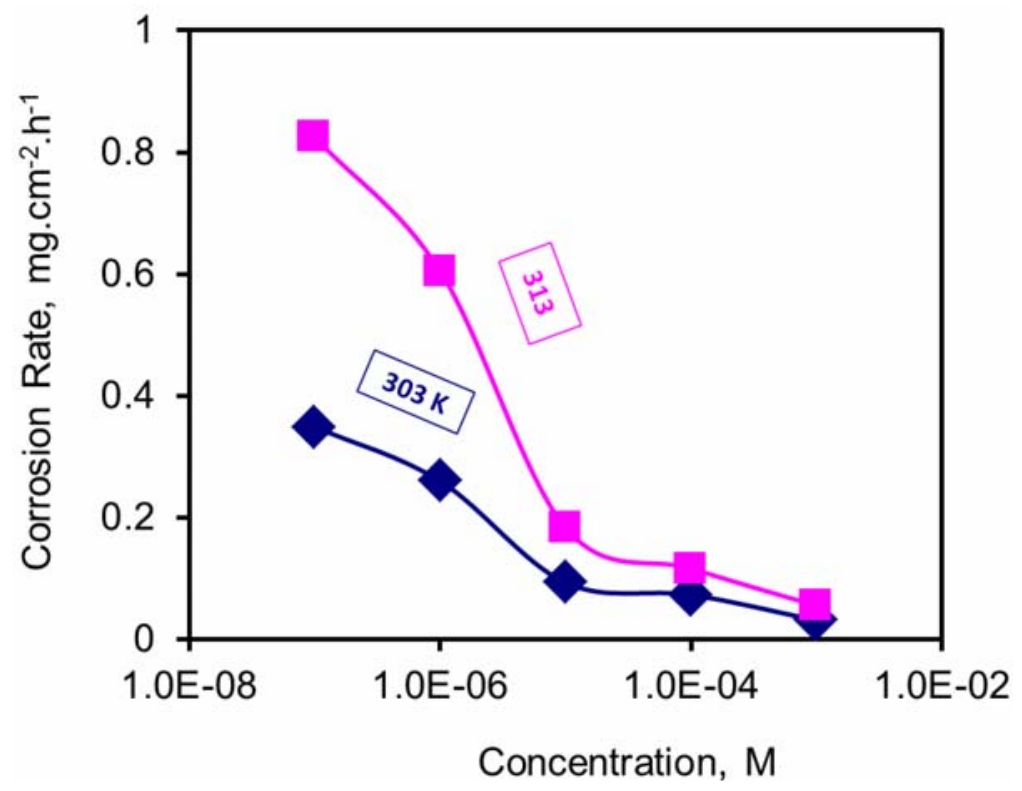

Figure 4. Effect of concentration of 1,4-dimethyl phenyl-N,Ndimethylanilinium dibromide on the corrosion rate $\left(\mathrm{mg} \cdot \mathrm{cm}^{-2} \cdot \mathrm{h}^{-1}\right)$ of mild steel in $1.0 \mathrm{M} \mathrm{HCl}$ at various temperatures.

• $303 \mathrm{~K} \quad$ - $313 \mathrm{~K}$ 


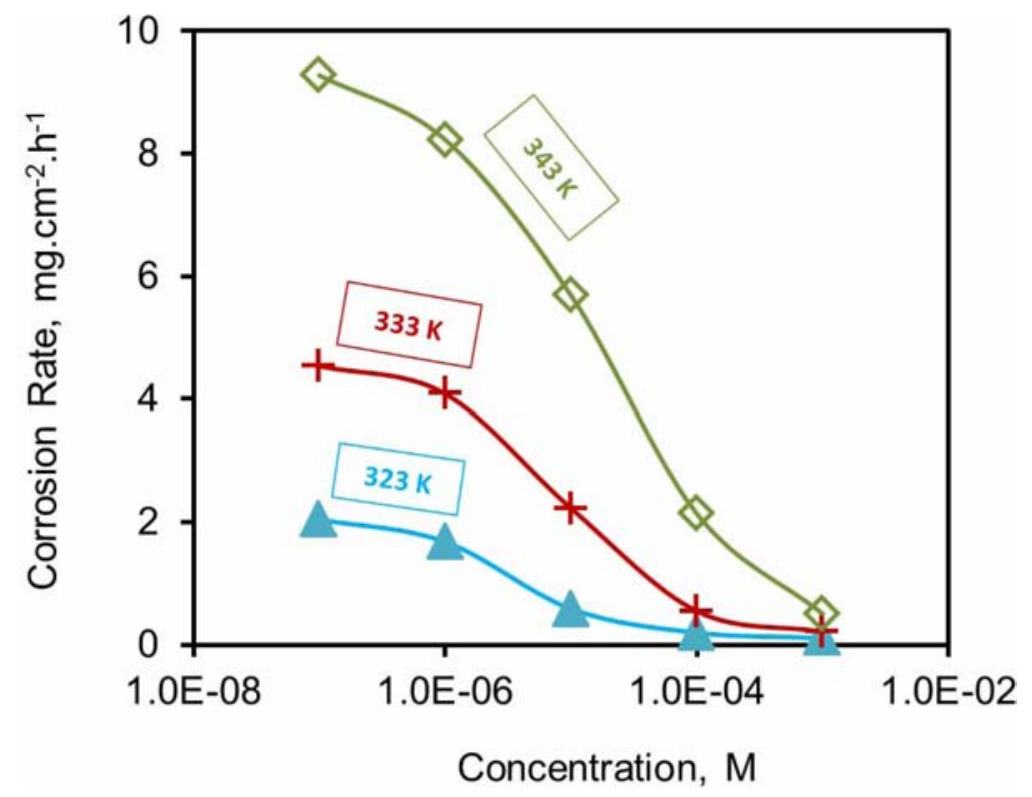

Figure 5. Effect of concentration of 1,4-dimethyl phenyl-N,Ndimethylanilinium dibromide on the corrosion rate $\left(\mathrm{mg} \cdot \mathrm{cm}^{-2} \cdot \mathrm{h}^{-1}\right)$ of mild steel in $1.0 \mathrm{M} \mathrm{HCl}$ at various temperatures.

$\Delta 323 \mathrm{~K} \quad \mathbf{+} 333 \mathrm{~K} \quad \diamond 343 \mathrm{~K}$

At $313 \mathrm{~K}$ (Figure 4), the curve showed a similar shape as that obtained at $303 \mathrm{~K}$. At concentrations greater than $1.0 \times 10^{-7} \mathrm{M}$, the corrosion rate decreased steeply and reached about $0.070 \mathrm{mg} . \mathrm{cm}^{-2} \cdot \mathrm{h}^{-1}$ $(92.3 \%)$ at $1.0 \times 10^{-4} \mathrm{M}$.

The corrosion rate at $323 \mathrm{~K}, 333 \mathrm{~K}$, and $343 \mathrm{~K}$ with different concentrations of the (DMPMA) inhibitor are shown in Figure 5. It is clearly noticed that the presence of the (DMPMA) inhibitor at these high temperatures still acted as an excellent corrosion inhibitor reaching a maximum percent inhibition of $94.7 \%$ with $1 \times 10^{-3} \mathrm{M}$ inhibitor at $343 \mathrm{~K}$. 
There was a slight effect on the corrosion rate at low and high concentrations of the inhibitor (between $1.0 \times 10^{-7} \mathrm{M}$ and $1.0 \times 10^{-6} \mathrm{M}$ ) and (between $1.0 \times 10^{-4} \mathrm{M}$ and $1.0 \times 10^{-3} \mathrm{M}$ ) at all temperatures; whereas this rate was large at intermediate concentrations (from $1.0 \times 10^{-6} \mathrm{M}$ to $\left.1.0 \times 10^{-4} \mathrm{M}\right)$.

The plots of the percentage of inhibition as a function of the inhibitor concentration at various temperatures $(303 \mathrm{~K}-343 \mathrm{~K})$ are shown in Figure 6 . This figure showed that the percentage of inhibition decreases with the increase of temperature.

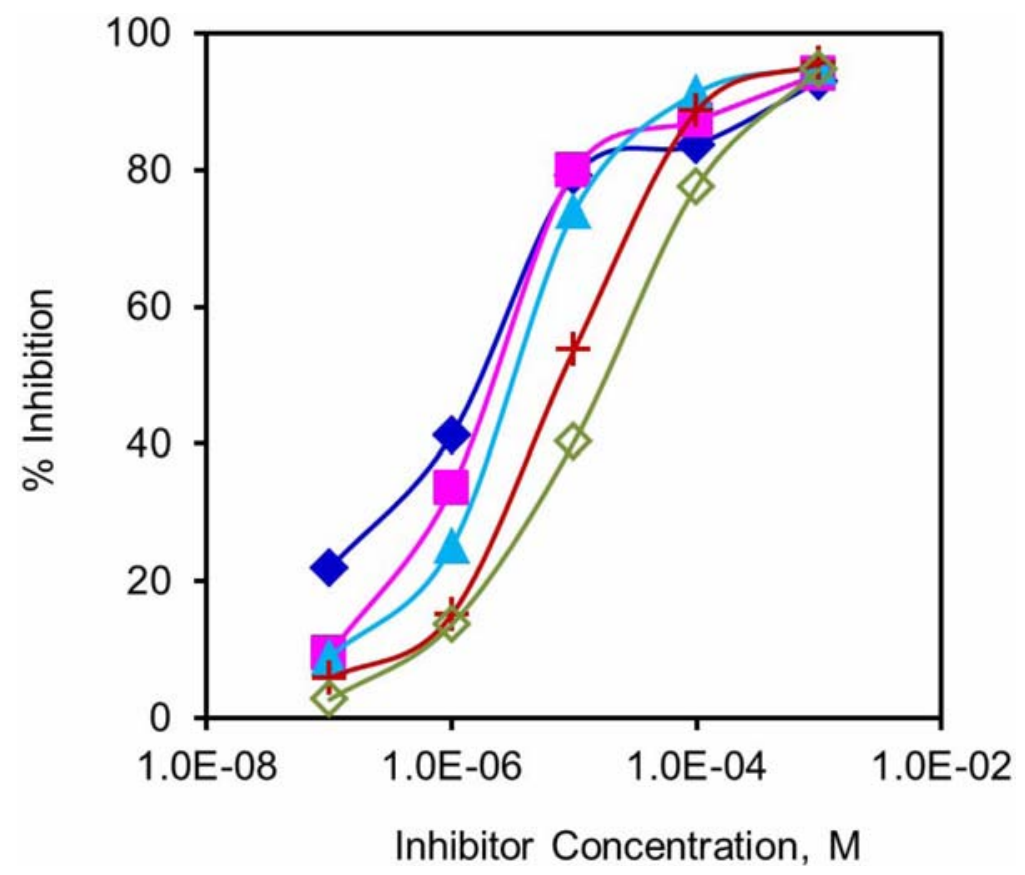

Figure 6. Effect of concentration of 1,4-dimethyl phenyl-N,Ndimethylanilinium dibromide on the percent inhibition of mild steel in $1.0 \mathrm{M} \mathrm{HCl}$ at various temperatures.

• $303 \mathrm{~K} \quad \boldsymbol{\square} 313 \mathrm{~K} \quad \boldsymbol{\Delta} 323 \mathrm{~K} \quad \boldsymbol{+} 333 \mathrm{~K} \diamond 343 \mathrm{~K}$ 
The data obtained from the weight loss measurements were plotted in accordance to Arrhenius equation:

$$
\ln \text { rate }=-\frac{E_{\mathrm{a}}}{R T}+\text { const. }
$$

where: $E_{\mathrm{a}}=$ activation energy [kcal.mol $\left.{ }^{-1}\right], R=$ gas constant $\left[\mathrm{kcal} . \mathrm{mol}^{-1}\right]$, $T=$ absolute temperature $[\mathrm{K}]$, and const. $=$ constant .

The Arrhenius plot of the corrosion of mild steel in $1.0 \mathrm{M} \mathrm{HCl}$ solution (Ln corrosion rate as a function of $1 / T$, Table 3 ) with and without the presence of (DMPMA) at various concentrations $\left(1.0 \times 10^{-7} \mathrm{M}\right.$ $-1.0 \times 10^{-3} \mathrm{M}$ ) is shown in Figure 7. From this figure, the activation energy was calculated according to Equation (3), and taking $\mathrm{R}=1.987 \times$ $10^{-3} \mathrm{kcal}_{\mathrm{mol}}{ }^{-1}$ (Table 4). It was found the activation energy increases with the increase of concentration of (DMPMA) as tabulated in (Table 4). This means that as the temperature increases the adsorption of the inhibitor on the metal surface decreases. This also suggests that the corrosion rate increases due to the greater exposed area of the metal surface to the acidic media. 
Table 3. The data obtained from the weight loss measurements for Arrhenius equation: $(1 / T)$ against Ln corrosion rate

\begin{tabular}{|c|c|c|c|c|c|c|}
\hline \multirow[b]{2}{*}{$(1 / T) \times 10^{3} K^{-1}$} & \multicolumn{6}{|c|}{ Ln corrosion rate $\left(\mathrm{mg} . \mathrm{cm}^{-2} \cdot \mathrm{h}^{-1}\right)$} \\
\hline & $\begin{array}{c}1.0 \mathrm{M} \\
\mathrm{HCl}\end{array}$ & $\begin{array}{c}1.0 \mathrm{M} \mathrm{HCl} \\
+1.0 \times 10^{-3} \mathrm{M}\end{array}$ & $\begin{array}{r}1.0 \mathrm{M} \mathrm{HCl} \\
+1.0 \times 10^{-4} \mathrm{M}\end{array}$ & $\begin{array}{c}1.0 \mathrm{M} \mathrm{HCl} \\
+1.0 \times 10^{-5} \mathrm{M}\end{array}$ & $\begin{array}{r}1.0 \mathrm{M} \mathrm{HCl} \\
+1.0 \times 10^{-6} \mathrm{M}\end{array}$ & $\begin{array}{r}1.0 \mathrm{M} \mathrm{HCl} \\
+1.0 \times 10^{-7} \mathrm{M}\end{array}$ \\
\hline 3.30 & -0.807 & -4.605 & -3.576 & -2.590 & -1.347 & -1.053 \\
\hline 3.19 & -0.094 & -3.507 & -2.659 & -1.700 & -0.502 & -0.192 \\
\hline 3.10 & 0.8083 & -2.465 & -1.630 & -0.536 & 0.519 & 0.715 \\
\hline 3.00 & 1.5711 & -1.546 & -0.601 & 0.800 & 1.407 & 1.512 \\
\hline 2.92 & 2.2552 & -0.683 & 0.750 & 1.773 & 2.108 & 2.228 \\
\hline
\end{tabular}


Table 4. The activation energy $\left(E_{\mathrm{a}}\right)$ for the corrosion of mild steel in 1.0 $\mathrm{M} \mathrm{HCl}$ with and without 1,4-dimethyl phenyl-N,N-dimethylanilinium dibromide inhibitor at various concentrations

\begin{tabular}{|c|c|c|c|c|c|}
\hline System & \multicolumn{5}{|c|}{ Activation energy, $E_{\mathrm{a}}\left(\mathrm{kcal} \mathrm{mol}^{-1}\right)$} \\
\hline & $1.0 \times 10^{-3} \mathrm{M}$ & $1.0 \times 10^{-4} \mathrm{M}$ & $1.0 \times 10^{-5} \mathrm{M}$ & $1.0 \times 10^{-6} \mathrm{M}$ & $1.0 \times 10^{-7} \mathrm{M}$ \\
\hline $1.0 \mathrm{M} \mathrm{HCl}$ & 16.09 & 16.09 & 16.09 & 16.09 & 16.09 \\
\hline $\begin{array}{c}\text { 1.0 M HCl } \\
+ \text { Inhibitor }\end{array}$ & 14.25 & 17.01 & 22.09 & 18.19 & 17.09 \\
\hline
\end{tabular}

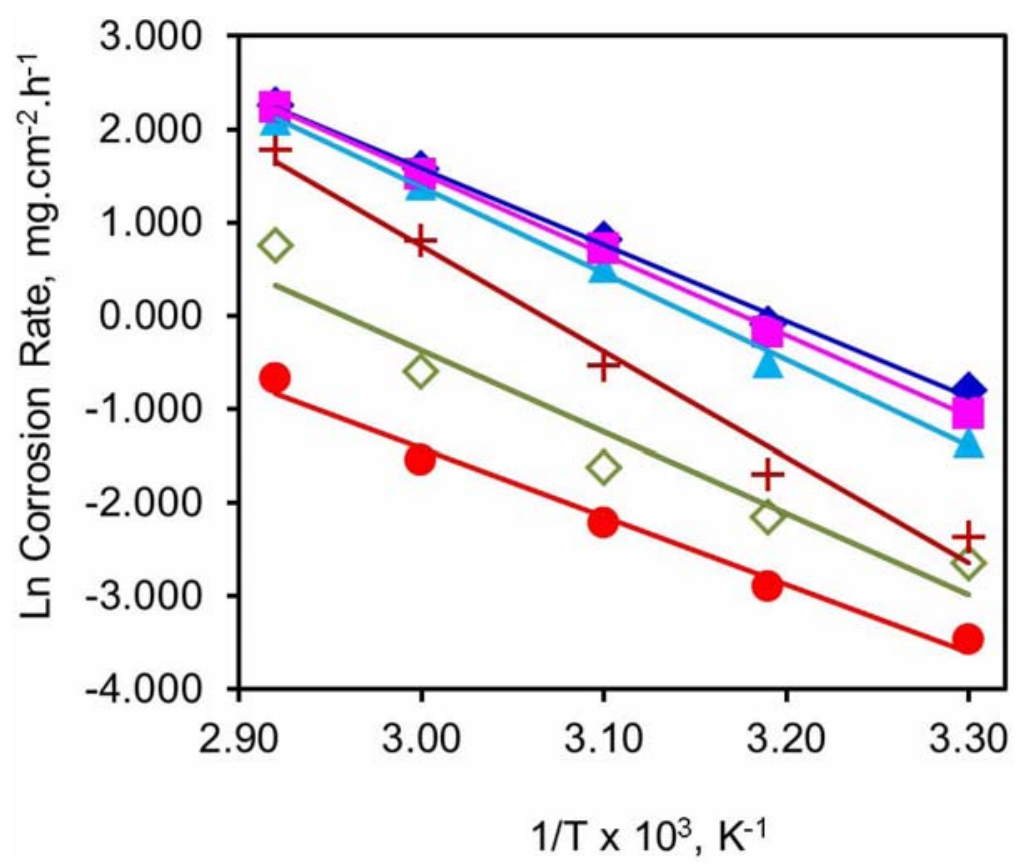

Figure 7. Effect of temperature on the corrosion rate of mild steel in 1.0 $\mathrm{M} \mathrm{HCl}$ solution with and without the presence of various concentrations of 1,4-dimethyl phenyl-N,N-dimethylanilinium dibromide.
$\bullet 1.0 \mathrm{M} \mathrm{HCl}$
- $1.0 \times 10^{-7} \mathrm{M}$
А $1.0 \times 10^{-6} \mathrm{M}$
$+1.0 \times 10^{-5} \mathrm{M}$
$\diamond 1.0 \times 10^{-4} \mathrm{M}$
- $1.0 \times 10^{-3} \mathrm{M}$ 
It has been noticed that the activation energy $\left(E_{\mathrm{a}}\right)$ values for the corrosion of mild steel in the presence of the inhibitor are higher than the values in the absence of inhibitor at all concentrations $\left(1.0 \times 10^{-3} \mathrm{M}-\right.$ $\left.1.0 \times 10^{-7} \mathrm{M}\right)$. This behaviour may be attributed to the physisorption process, whereas unchanged or lower values of $E_{\mathrm{a}}$ in inhibited solution suggest a chemisorption process [33].

Table 5. Effect of concentration of 1,4-dimethyl phenyl-N,Ndimethylanilinium dibromide on surface coverage for mild steel in $1.0 \mathrm{M} \mathrm{HCl}$ at various temperatures

\begin{tabular}{|c|c|c|c|c|c|}
\hline & \multicolumn{5}{|c|}{ Temperature / K } \\
\hline & 303 & 313 & 323 & 333 & 343 \\
\hline $\begin{array}{l}\text { Concentration of } \\
\text { inhibitor }\end{array}$ & $\begin{array}{c}\text { Surface } \\
\text { coverage } \\
\theta\end{array}$ & $\begin{array}{c}\text { Surface } \\
\text { coverage } \\
\theta\end{array}$ & $\begin{array}{c}\text { Surface } \\
\text { coverage } \\
\theta\end{array}$ & $\begin{array}{c}\text { Surface } \\
\text { coverage } \\
\theta\end{array}$ & $\begin{array}{c}\text { Surface } \\
\text { coverage } \\
\theta\end{array}$ \\
\hline $1.0 \mathrm{M} \mathrm{HCl}+1.0 \times 10^{-7} \mathrm{M}$ & 0.219 & 0.094 & 0.089 & 0.058 & 0.027 \\
\hline $1.0 \mathrm{M} \mathrm{HCl}+1.0 \times 10^{-6} \mathrm{M}$ & 0.413 & 0.335 & 0.251 & 0.151 & 0.137 \\
\hline $1.0 \mathrm{M} \mathrm{HCl}+1.0 \times 10^{-5} \mathrm{M}$ & 0.792 & 0.799 & 0.740 & 0.538 & 0.404 \\
\hline $1.0 \mathrm{M} \mathrm{HCl}+1.0 \times 10^{-4} \mathrm{M}$ & 0.937 & 0.923 & 0.913 & 0.886 & 0.776 \\
\hline $1.0 \mathrm{M} \mathrm{HCl}+1.0 \times 10^{-3} \mathrm{M}$ & 0.978 & 0.967 & 0.962 & 0.956 & 0.947 \\
\hline
\end{tabular}

The surface coverage values, $\theta$, of various concentrations $\left(1.0 \times 10^{-3} \mathrm{M}\right.$ $\left.-1.0 \times 10^{-7} \mathrm{M}\right)$ of (DMPMA) on mild steel surface at various temperatures are tabulated in Table 5. These values were extracted from the corresponding \% efficiency values reported earlier in Table 2. The plot of surface coverage, $\theta$, against the natural logarithm of the concentration, $\ln C$, for mild steel in the presence of the various inhibitor concentrations is shown in Figure 8. After examining the data and 
adjusting them to different theoretical adsorption isotherms, it was concluded that all inhibitors were adsorbed on the mild steel surface according to Temkin isotherm:

$$
-2 a \theta=\ln K C
$$

where: $\quad a=$ molecular interaction constant,

$$
\begin{aligned}
& \theta=\text { degree of coverage, } \\
& K=\text { equilibrium constant for the adsorption reaction, and } \\
& C=\text { concentration of the inhibitor. }
\end{aligned}
$$

The equilibrium constant for the adsorption reaction, $K$, is related to the standard free energy of adsorption via the following Equation (5) [34]:

$$
K=\frac{1}{55.5} \exp \left(-\frac{\Delta G}{R T}\right)
$$

where: $K=$ equilibrium constant for the adsorption reaction,

$$
\begin{aligned}
& 55.5=\text { concentration of water }\left[\mathrm{mol} . \mathrm{L}^{-1}\right], \\
& \Delta G=\text { standard free energy }\left[\mathrm{kcal} . \mathrm{mol}^{-1}\right], \\
& R=\text { gas constant }\left[\mathrm{kcal} . \mathrm{mol}^{-1}\right], \text { and } \\
& T=\text { absolute temperature }[K] .
\end{aligned}
$$

According to Equation (4), the straight lines shown in Figure 4 will have the following slopes and intercepts:

$$
\begin{gathered}
\text { Slope }=-\frac{1}{2 a} ; \\
\text { Intercept }=-\frac{1}{2 a} \ln K .
\end{gathered}
$$

Combination of Equations (6) and (7) leads to the following relationship:

$$
\text { Intercept }=\text { Slope. }(\ln K) \text {, }
$$


from which the equilibrium constant for the adsorption reaction, $K$, can be calculated:

$$
K=e^{\left(\frac{\text { Intercept }}{\text { Slope }}\right)} .
$$

The values of the standard free energy of adsorption of the inhibitor, $\Delta \mathrm{G}^{0}$, were calculated from the results in Figure 8 and using the previous Equation (5) at various temperatures (303 K-343 K), see Table 6.

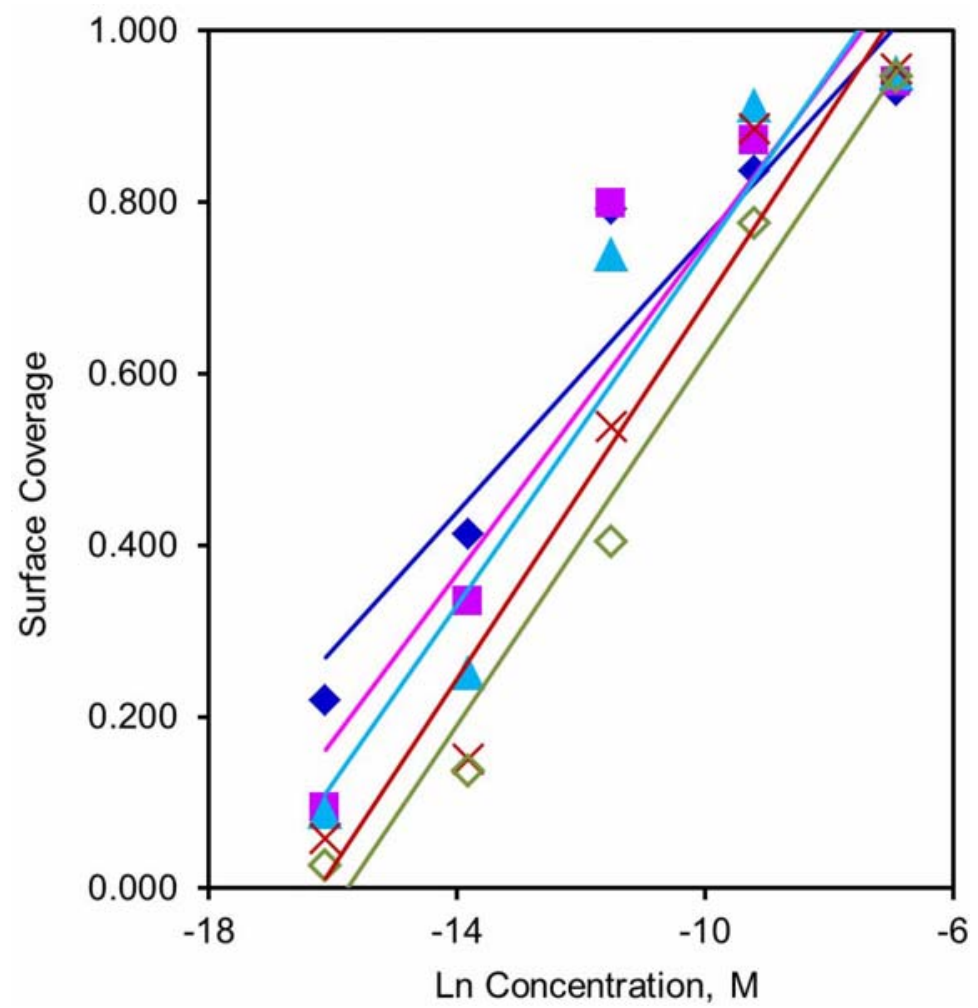

Figure 8. Effect of concentration of 1,4-dimethyl phenyl-N,Ndimethylanilinium dibromide on the surface coverage of mild steel in $1.0 \mathrm{M} \mathrm{HCl}$ at various temperatures.

$\bullet 303 \mathrm{~K}$

- $313 \mathrm{~K}$

$\Delta 323 \mathrm{~K} \quad \boldsymbol{+} 333 \mathrm{~K}$

$\diamond 343 \mathrm{~K}$ 
Table 6. The free energy of adsorption $\left(\Delta \mathrm{G}_{\mathrm{ads}}\right)$ for mild steel in $1.0 \mathrm{M} \mathrm{HCl}$ in the presence of 1,4-dimethyl phenyl-N,N-dimethylanilinium dibromide at various temperatures (303 K-343 K).

\begin{tabular}{|c|c|c|c|c|}
\hline \multicolumn{5}{|c|}{$\Delta \mathrm{G}, \mathrm{kcal}_{\mathrm{mol}}{ }^{-1}$} \\
\hline $303 \mathrm{~K}$ & $313 \mathrm{~K}$ & $323 \mathrm{~K}$ & $333 \mathrm{~K}$ & $343 \mathrm{~K}$ \\
\hline-14.14 & -13.57 & -13.62 & -13.39 & -13.49 \\
\hline
\end{tabular}

The values of the enthalpy of adsorption, $\Delta \mathrm{H}^{0}$, (Table 7 ), for the inhibitor were calculated from the following equation:

$$
\Delta \mathrm{H}^{0}=E_{\mathrm{a}}-\mathrm{RT} \text {. }
$$

Table 7. The enthalpy of adsorption $(\Delta \mathrm{H})$ for mild steel in $1.0 \mathrm{M} \mathrm{HCl}$ in the presence of $1.0 \times 10^{-3} \mathrm{M}$ 1,4-dimethyl phenyl-N,N-dimethylanilinium dibromide at various temperatures (303 K-343 K)

\begin{tabular}{|c|c|c|c|c|}
\hline \multicolumn{5}{|c|}{$\Delta$ H, kcal.mol } \\
\hline $\mathbf{1}$ \\
\hline $\mathbf{3 0 3} \mathbf{~ K}$ & $\mathbf{3 1 3} \mathbf{~ K}$ & $\mathbf{3 2 3} \mathbf{~ K}$ & $\mathbf{3 3 3} \mathbf{~}$ & $\mathbf{3 4 3} \mathbf{~ K}$ \\
\hline 13.65 & 13.63 & 13.61 & 13.59 & 13.57 \\
\hline
\end{tabular}

The values of entropy, $\Delta \mathbf{S}^{0}$, (Table 8), were calculated at various temperatures for the inhibitor using the following equation:

$$
\Delta \mathrm{G}^{0}=\Delta \mathrm{H}^{0}-\mathrm{T} \Delta \mathrm{S}^{0}
$$

Table 8. The change in entropy $(\Delta \mathrm{S})$ for mild steel in $1.0 \mathrm{M} \mathrm{HCl}$ in the presence of 1,4-dimethyl phenyl-N,N-dimethylanilinium dibromide at various temperatures (303 K-343 K)

\begin{tabular}{|l|c|c|c|c|}
\hline \multicolumn{5}{|c|}{$\Delta$ S, kcal.K ${ }^{-\mathbf{1}} \mathbf{m o l}^{-\mathbf{1}}$} \\
\hline $\mathbf{3 0 3} \mathbf{~ K}$ & $\mathbf{3 1 3} \mathbf{K}$ & $\mathbf{3 2 3} \mathbf{~ K}$ & $\mathbf{3 3 3} \mathbf{~ K}$ & $\mathbf{3 4 3} \mathbf{~ K}$ \\
\hline 0.092 & 0.087 & 0.084 & 0.081 & 0.079 \\
\hline
\end{tabular}


Tables 6 to 8 show the thermodynamic data obtained in the presence

of the inhibitor at $1.0 \times 10^{-3} \mathrm{M}$. These thermodynamic quantities represent the algebraic sum of the values for adsorption and desorption. The spontaneity adsorption of the inhibitor on the mild steel surface was noticed from the negative sign of $\Delta \mathrm{G}^{0}$ values. The standard free energy, $\Delta \mathrm{G}^{0}$, varies from $-14.14 \mathrm{kcal} \cdot \mathrm{mol}^{-1} \cdot \mathrm{K}^{-1}$ at $303 \mathrm{~K}$ to $-13.49 \mathrm{kcal} \cdot \mathrm{mol}^{-1} \cdot \mathrm{K}^{-1}$ at $343 \mathrm{~K}$. The absolute of these values is less than $20 \mathrm{kcal} \cdot \mathrm{mol}^{-1} \cdot \mathrm{K}^{-1}$, which also indicates a physisorption process. The positive enthalpy values, indicates that the adsorption process is an exothermic and associated with a decrease in entropy $(\Delta S)$ of solute, while the opposite is true for the solvent resulting in a net increase of entropy for the whole system. The gain in entropy which accompanies the substitutional adsorption process is attributed to the increase in the solvent entropy. This is in agreement with the general suggestion that the values of $\Delta \mathrm{G}^{0}$ increase with the increase of inhibition efficiency due to adsorption desorption process [23, 35].

The high inhibition efficiency may be attributed to the preferred flat orientation of this compound on the metal surface. The interaction occurs between the $\pi$-electrons of the three benzene rings.

\section{Conclusion}

1,4-dimethyl phenyl-N,N-dimethylanilinium dibromide (DMPMA) was found to be a very efficient inhibitor for mild steel in $1.0 \mathrm{M} \mathrm{HCl}$ solution, reaching about $98 \%$ with inhibitor concentration $1.0 \times 10^{-3} \mathrm{M}$ at $303 \mathrm{~K}$.

1,4-dimethyl phenyl-N,N-dimethylanilinium dibromide (DMPMA) is a potential corrosion inhibitor since it contains three phenyl rings. It was apparent from the molecular structure that this compound would be adsorbed on the metal surface through the $\pi$-electrons of the three benzene rings. 
The decrease of the percentage inhibition in the presence of this inhibitor with the increase of temperature, as well as the values of activation energy and free energy, suggested that the physical adsorption was the predominant inhibition mechanism.

\section{References}

[1] T. Tüken, B. Yazici and M. Erbil, The effect of nicotinamide on iron corrosion in chloride solutions, Turkish Journal of Chemistry 26(5) (2002), 735-742.

[2] J. D. Talati, M. N. Desai and N. K. Shah, meta-Substituted aniline- $N$-salicylidenes as corrosion inhibitors of zinc in sulphuric acid, Materials Chemistry and Physics 93(1) (2005), 54-64.

DOI: https://doi.org/10.1016/j.matchemphys.2005.02.004

[3] A. Nahlé, I. Abu-Abdoun and I. Abdel-Rahman, Corrosion inhibition of (anthraquinone-2-ylmethyl) triphenyl phosphonium bromide on mild steel in $\mathrm{HCl}$ solution, Bulletin of Electrochemistry 23 (2007), 201-209.

[4] A. Popova, Temperature effect on mild steel corrosion in acid media in presence of azoles, Corrosion Science 49(5) (2007), 2144-2158.

DOI: https://doi.org/10.1016/j.corsci.2006.10.020

[5] I. Aiad and N. A. Negm, Some corrosion inhibitors based on Schiff base surfactants for mild steel equipments, Journal of Dispersion Science and Technology 30(8) (2009), 1142-1147.

DOI: https://doi.org/10.1080/01932690802701598

[6] K. Tebbji, A. Aouniti, A. Attayibat, B. Hammouti, H. Oudda, M. Benkaddour, S. Radi and A. Nahlé, Inhibition efficiency of two bipyrazole derivatives on steel corrosion in hydrochloric acid media, Indian Journal of Chemical Technology 18(3) (2011), 244-253.

[7] A. Nahlé, Ideisan I. Abu-Abdoun and I. Abdel-Rahman, Inhibition of mild steel corrosion by 3-benzoylmethyl benzimidazolium hexafluoroantimonate in acidic solution, International Journal of Corrosion (2012), Article ID 246013, 10 pages.

DOI: https://doi.org/10.1155/2012/246013

[8] A. Nahlé, Ideisan I. Abu-Abdoun and I. Abdel-Rahman, Effect of temperature on the corrosion inhibition of trans-4-hydroxy-4'-stilbazole on mild steel in $\mathrm{HCl}$ solution, International Journal of Corrosion (2012), Article ID 380329, 7 pages.

DOI: https://doi.org/10.1155/2012/380329 
[9] R. Baskar, D. Kesavan, M. Gopiraman and K. Subramanian, Corrosion inhibition of mild steel in 1.0M hydrochloric acid medium by new photo-cross-linkable polymers, Progress in Organic Coatings 77(4) (2014), 836-844.

DOI: https://doi.org/10.1016/j.porgcoat.2014.01.013

[10] B. P. Markhali, R. Naderi, M. Sayebani and M. Mahdavian, Corrosion inhibition of some azole derivatives on carbon steel in hydrochloric acid solution, Anti-Corrosion Methods and Materials 61(5) (2014), 300-306.

DOI: https://doi.org/10.1108/ACMM-05-2013-1266

[11] A. Nahlé, I. Abu-Abdoun and I. Abdel-Rahman, Corrosion inhibition of 1-vinylimidazole-3-phenacyl hexafluoroantimonate salt on mild steel in $\mathrm{HCl}$ solution, International Journal of Corrosion and Scale Inhibition 4(3) (2015), 255-268.

DOI: https://doi.org/10.17675/2305-6894-2015-4-3-255-268

[12] N. K. Gupta, C. Verma, M. A. Quraishi and A. K. Mukherjee, Schiff's bases derived from L-lysine and aromatic aldehydes as green corrosion inhibitors for mild steel: Experimental and theoretical studies, Journal of Molecular Liquids 215 (2016), 47-57.

DOI: https://doi.org/10.1016/j.molliq.2015.12.027

[13] M. A. J. Mazumder, Synthesis and evaluation of new isoxazolidine derivatives of aldehyde as corrosion inhibitors for mild steel corrosion in acidic and saline media, International Journal of Electrochemical Science 11(5) (2016), 4050-4075.

DOI: https://doi.org/10.20964/110257

[14] I. Chakib, H. Elmsellem, N. K. Sebbar, S. Lahmidi, A. Nadeem, E. M. Essassi, Y. Ouzidan, I. Abdel-Rahman, F. Bentiss and B. Hammouti, Electrochemical, gravimetric and theoretical evaluation of (4Z)-2,5-dimethyl-4-(4-methylpyrimido[1,2a]benzimidazol-2(1H)-ylidene)-2,4-dihydro-3H-pyrazol-3-one (P1) as a corrosion inhibitor for mild steel in $1 \mathrm{M} \mathrm{HCl}$ solution, Journal of Materials and Environmental Science 7(6) (2016), 1866-1881.

[15] M. Ellouz, H. Elmsellem, N. K. Sebbar, H. Steli, K. Al Mamari, A. Nadeem, Y. Ouzidan, E. M. Essassi, I. Abdel-Rahaman and P. Hristov, Anti-corrosive properties of benzothiazine derivatives on mild steel corrosion in $1 \mathrm{M} \mathrm{HCl}$ solution: Experimental and theoretical studies, Journal of Materials and Environmental Science 7(7) (2016), 2482-2497.

[16] M. Ellouz, N. K. Sebbar, H. Elmsellem, H. Steli, I. Fichtali, M. M. Mohamed Abdelahi, K. Al Mamari, E. M. Essassi and I. Abdel-Rahaman, Inhibitive properties and quantum chemical studies of 1,4-benzothiazine derivatives on mild steel corrosion in acidic medium, Journal of Materials and Environmental Science 7(8) (2016), 2806-2819. 
[17] M. Y. Hjouji, M. Djedid, H. Elmsellem, Y. Kandri Rodi, Y. Ouzidan, F. Ouazzani Chahdi, N. K. Sebbar, E. M. Essassi, I. Abdel-Rahman and B. Hammouti, Corrosion inhibition of mild steel in hydrochloric acid solution by pyrido[2,3-b]pyrazine derivative: Electrochemical and theoretical evaluation, Journal of Materials and Environmental Science 7(4) (2016), 1425-1435.

[18] S. Lahmidi, A. Elyoussfi, A. Dafali, H. Elmsellem, N. K. Sebbar, L. El Ouasif, A. F. Jilalat, B. El Mahi, E. M. Essassi, I. Abdel-Rahman and B. Hammouti, Corrosion inhibition of mild steel by two new 1,2,4-triazolo[1,5-a]pyrimidine derivatives in $1 \mathrm{M}$ $\mathrm{HCl}$ : Experimental and computational study, Journal of Materials and Environmental Science 8(1) (2017), 225-237.

[19] B. C. Ateya, B. E. El-Anadouli and F. M. El-Nizamy, The effect of thiourea on the corrosion kinetics of mild steel in $\mathrm{H}_{2} \mathrm{SO}_{4}$, Corrosion Science 24(6) (1984), 497-507.

DOI: https://doi.org/10.1016/0010-938X(84)90032-5

[20] A. S. Fouda, M. N. Mousa, F. I. Taha and A. I. Elneanaa, The role of some thiosemicarbazide derivatives in the corrosion inhibition of aluminum in hydrochloric acid, Corrosion Science 26(9) (1986), 719-726.

DOI: https://doi.org/10.1016/0010-938X(86)90035-1

[21] S. N. Raicheva, B. V. Aleksiev and E. I. Sokolova, The effect of the chemical structure of some nitrogen- and sulphur-containing organic compounds on their corrosion inhibiting action, Corrosion Science 34(2) (1993), 343-350.

DOI: https://doi.org/10.1016/0010-938X(93)90011-5

[22] S. H. Sanad, A. A. Ismail and A. A. El-Meligi, The effect of temperature on the corrosion and corrosion inhibition of steel alloys in hydrochloric acid solutions, Bulletin of Electrochemistry 11(10) (1995), 462-469.

[23] A. Nahlé, Effect of temperature on the corrosion inhibition of carbon steel in $\mathrm{HCl}$ solutions, Bulletin of Electrochemistry 17(5) (2001), 221-226.

[24] A. Nahlé, Inhibition of corrosion of iron in $\mathrm{HCl}$ solution by semicarbazides and thiosemicarbazides, Bulletin of Electrochemistry 21(6) (2005), 275-281.

[25] A. Nahlé, I. Abdel-Rahman and M. Alfarouk, Effect of temperature on the inhibition of corrosion of carbon steels by semicarbazides and thiosemicarbazides, Bulletin of Electrochemistry 21(8) (2005), 353-361.

[26] K. F. Khaled and N. S. Abdel-Shafi, Corrosion inhibition of mild steel by some sulfur containing compounds: Artificial neural network modeling, Journal of Materials and Environmental Science 5(4) (2014), 1288-1297.

[27] A. Nahlé, I. Abu-Abdoun and I. Abdel-Rahman, Electrochemical studies of the effect of trans-4-hydroxy-4'-stilbazole on the corrosion inhibition of mild steel in $\mathrm{HCl}$ solution, Anti-Corrosion Methods and Materials 54(4) (2007), 244-248.

DOI: https://doi.org/10.1108/00035590710762393 
[28] A. Nahlé, M. Al-Khayat, I. Abu-Abdoun and I. Abdel-Rahman, Corrosion inhibition of mild steel by P,P'-Bis (triphenylphosphonio) methyl benzophenone dibromide in HCl solution, Anti-Corrosion Methods and Materials 60(1) (2013), 20-27.

DOI: https://doi.org/10.1108/00035591311287410

[29] A. Nahlé, I. Abu-Abdoun and I. Abdel-Rahman, Corrosion inhibition on mild steel in $1.0 \mathrm{M} \mathrm{HCl}$ solution by 1-vinylimidazolium-3-methyltriphenyl phosphonium dihexafluoroantimonate salt, Journal of Materials and Environmental Science 7(8) (2016), 2955-2964.

[30] Xiang Gao, Shaotong Liu, Haifeng Lu, Feng Gao and Houyi Ma, Corrosion inhibition of iron in acidic solutions by monoalkyl phosphate esters with different chain lengths, Industrial \& Engineering Chemistry Research 54(7) (2015), 1941-1952.

\section{DOI: https://doi.org/10.1021/ie503508h}

[31] K. Kobayashi, K. Shimizu and M. Iida, Structural effects of organic compounds as corrosion inhibitors for hydrogen entry into iron in sulfuric acid, Corrosion Science 35(5-8) (1993), 1431-1435.

\section{DOI: https://doi.org/10.1016/0010-938X(93)90368-Q}

[32] L. D. Skryler, E. A. Streltsova and T. L. Skryleva, Hydrocarbon chain length and inhibitive action of alkylammonium chlorides, Zashchita Metallov 27(6) (1991), 977-980.

[33] A. Popova, M. Christov, S. Raicheva and E. Sokolova, Adsorption and inhibitive properties of benzimidazole derivatives in acid mild steel corrosion, Corrosion Science 46(6) (2004), 1333-1350.

DOI: https://doi.org/10.1016/j.corsci.2003.09.025

[34] B. B. Damaskin, O. A. Pietrij and W. W. Batrokov, Adsorpcja organiczeskich sojedinienij na electrodach, Moskva, 1968.

[35] A. S. Fouda, A. Abd El-Aal and A. B. Kandil, The effect of some phthalimide derivatives on the corrosion behaviour of copper in nitric acid, Anti-Corrosion Methods and Materials 52(2) (2005), 96-101.

DOI: https://doi.org/10.1108/00035590510584807 